\title{
ENTRE O AUTO-ESPETÁCULO E A OPINIÃO DOS OUTROS
}

por Luisa Günther*

DABUL, Lígia. Um percurso da pintura: a produção de identidades de artista. Niterói: EDUFF, 2001. 240 p.

Um artista é uma pessoa que tem vários artistas dentro de si.

Nelson Lernier

Os olhos só pintam o que a alma percebe, mas de que corpo faz parte esta alma? Qualquer um pode ser artista? Mediante uma relativização da consagração pública como ratificação da condição de artista, Lígia Dabul desenvolve no decorrer das páginas de $U m$ percurso da pintura: a produção de identidades de artista considerações sobre os mecanismos sociais de conformação da identidade do artista plástico, sendo este metodologicamente limitado à figura daquele que pinta. Este livro é uma versão da dissertação apresentada, em 1998, à área de Antropologia da Arte do Mestrado em História da Arte, da Escola de Belas Artes da UFRJ e fundamentase em pesquisa etnográfica realizada por mais de um ano e meio em uma turma noturna de pintura da Escola de Artes Visuais do Parque Lage, no Rio de Janeiro.

As preocupações da autora originam-se, por um lado, da constatação do não tratamento da trajetória de artistas anterior a

* Mestranda em Sociologia, UnB 
suas situações de consagração por parte dos teóricos da História da Arte e, por outro, é reação ao privilégio concedido à análise do objeto artístico como se este fosse síntese e evidência de processos sociais por parte da Antropologia da Arte. Nestes termos, reside o interesse em compreender como situações sociais experimentadas de maneira direta por artistas em devir explicariam seus atos, entre estes, a confecção de objetos artísticos. Partindo da premissa que a condição de artista não é inerente nem dada ao ator social, mas construída pelas relações sociais que as pessoas estabelecem entre si - premissa esta fundamentada nas produções teóricas de Pierre Bourdieu e Howard Becker -, Lígia Dabul pondera em que medida as práticas sociais atualizadas em um meio artístico e a aceitação ou não de sua produção interferem na constituição da identidade de um pintor enquanto artista.

Ao ser observador-participante em um curso de pintura da Escola de Artes Visuais do Parque Lage, a pesquisadora pôde, então, refletir sobre as formas como realizadores de objetos por um meio já consagrado - pintura sobre tela - constroem sua maneira de conceber a produção artística e a si mesmos. Ao leitor é apresentado o detalhamento do cotidiano de uma aula de pintura, desde as relações espaciais entre os atores mesmos e o ambiente, até os exercícios confeccionados em sala e as dificuldades pictóricas da própria autora. Em meio à explicitação do uso expressivo de elementos da sintaxe da linguagem visual preconizada pelo professor, a leitura confrontase ainda com algumas carreiras artísticas de seus colegas de turma e com uma interessante contraposição entre o que seria característico da prática da "pintura contemporânea", associada às atividades desenvolvidas na Escola de Artes Visuais do Parque Lage, em relação à 'pintura acadêmica', localizada como característica dos procedimentos desenvolvidos na Escola de Belas Artes da UFRJ e implicações destas práticas para as questões identitárias.

No que tange à diferenciação entre estas duas concepções de pintura, as considerações da autora partem do ponto de vista nativo isto é, daqueles que praticam a "pintura contemporânea" no Parque Lage. Teria sido proveitosa à leitura uma maior problematização desta 
suposta dicotomia, o que poderia ter sido possível mediante a apresentação das opiniões daqueles que praticam a "pintura acadêmica" nesta outra localidade. Afinal, se a prática da pintura acadêmica ainda acontece em um dado momento histórico, ela ocorre mediante a atualização por atores sociais de determinados procedimentos técnicos, de determinadas concepções teóricas da sintaxe da linguagem visual (e.g., cor, composição, equilíbrio, relação figura/fundo). Por quê, então, a atualização desta prática não é considerada como sendo uma atividade contemporânea de pintura? Ademais, considerando que a criação artística é uma prática que depende da convenção adotada pelo artista, até que ponto procedimentos legitimados discursivamente enquanto característicos de uma atitude contemporânea de pintura pela figura autorizada do professor em uma aula não são tão institucionais quanto os da 'pintura acadêmica'? O que é mais artístico? Para quem?

Uma segunda ressalva provocada pela leitura diz respeito ao suposto esquecimento, por historiadores da arte, da prática dos artistas como componente da "condição para a confecção dos objetos e sobretudo como prática social tão ou mais importante para a compreensão do significado social da produção artística que o chamado consumo dos resultados desta produção” (p. 12). Entretanto, será que de fato estas práticas foram esquecidas? Não seria o próprio objeto artístico um legado material desta prática? Provavelmente por isso, a ênfase na leitura e análise do objeto por parte de alguns teóricos. Outrossim, uma obra de arte não é tãosomente um objeto, um documento cultural que atesta uma particular realidade sócio-histórica. A obra de arte é também, e talvez principalmente, em si mesma, um acontecido que se atualiza e se revela ao olhar atento daquele que nela busca uma evidência da atuação do artista que ali permanece como rastro. Nestes termos, se a prática da pintura for considerada não somente como prática, mas também como auto-espetacularização do artista, o carisma deste ator social é simultaneamente desmistificado e reificado quando este tornase produto já que, em última instância, sua glorificação sócio-histórica é ter transformado-se em um objeto digno de culto. Ademais, é preciso que seja explicitado que a curiosidade pública pelas considerações 
feitas por artistas sobre seus próprios procedimentos pictóricos de expressão, não na materialidade da obra, mas em outro contexto discursivo, é preocupação recente de pesquisadores em Arte, configurando-se no horizonte epistemológico deste campo de conhecimento apenas no presente momento, o que reitera a atualidade das questões propostas por Lígia Dabul neste livro.

De fato, uma das principais inovações no processo criativo de objetos artísticos característicos da Arte Moderna, e por extensão da Arte Contemporânea, foi a inclusão de considerações sobre a subjetividade da prática artística, sobre o processo criativo de um eu experimentalista, como o elemento determinante e característico de uma obra. Se até então fora privilegiado o conhecimento pertinente ao fazer artístico (o métier), eventualmente percebeu-se que as contínuas transformações formais acumuladas desde o Impressionismo (e.g., o estudo da cor em diferentes momentos de luz, a aplicação do pigmento puro através de pinceladas livres, a preferência por cenas cotidianas ao invés dos tradicionais temas históricos, míticos ou religiosos) resultavam, paradoxalmente, em um enfraquecimento do poder de inovação da forma pela técnica como manifestação visual exclusiva de um conteúdo. Eventualmente, uma maior ênfase foi dedicada às condições e aos efeitos da criação para o próprio artista algo que, por sua vez, justificaria a intenção formativa de uma obra. Atualmente é possível deparar-se com a publicação das cartas de Cézanne a Émile Bernard, de van Gogh a Theo, de Mário de Andrade a Tarsila do Amaral, de Lygia Clark a Hélio Oiticica, o diário de Paul Klee, as impressões etnográficas de Gauguin..., tendo sido editado ainda no século passado um valioso livro ${ }^{1}$ contendo um sem número de diferentes tipos de depoimentos de artistas modernos consagrados pela historiografia.

Por último, devo confessar que senti falta de imagens, fotografias que elucidassem quer os exercícios confeccionados em sala, quer os percursos pictóricos materializados nas telas, por mais que compreenda a necessidade de resguardar a privacidade dos que participaram da pesquisa. Entretanto, já que a autora era também 
uma das alunas nesta dinâmica, seus próprios trabalhos poderiam ter sido apresentados. Afinal, é senso comum que uma imagem vale mais que mil palavras, e em se tratando dos elementos sintáticos da linguagem visual, a escrita verbal deixada à mercê de si mesma não é suficiente para a visualização do processo pictórico que foi considerado pela autora, em certa medida, automático. Sem dúvida, em algum momento, a prática da pintura contém uma dimensão gestual que parece ser mesmice. Pode até ser que para alguns, pintar seja de fato uma atividade automática e repetitiva, mas se fosse tão somente isto, o que justificaria tanta comoção em torno de questões como dom, talento inato ou inspiração no que tange à produção artística? Nestes termos, não me causa espanto o fato de que, no decorrer de sua pesquisa, "alguns estranhavam eu não demonstrar interesse por processos criativos ou formas de criação e havia clara incompreensão sobre o quanto estar ali pintando, conversando e observando bastaria para o que me dispunha elucidar" (p. 40). No diálogo do fazer artístico, o que acontece entre o ator social, os objetos culturais e o conhecimento social que domina e como isto resulta em uma obra de arte é algo que somente pode ser compreendido, de fato, quando se considera o processo criativo em sua dimensão interpretativa e documental.

Em todo caso, Ligia Dabul ao enveredar por um caminho ainda pouco explorado em termos teóricos, metodológicos e etnográficos apresenta, em um texto de agradável leitura, importantes reflexões sobre os bastidores dos mecanismos de produção simbólica. Para futuras gerações de pesquisadores, seu livro é sem dúvida um marco teórico que pauta como a pintura é construída como prática e como esta prática, por sua vez, constitui uma determinada identidade social. Em sua nada fácil tarefa de proporcionar ao leitor a visualização dos significados sociais que subjazem à predisposição de adesão a uma determinada concepção artística e a um modo de praticá-la, é fiel à sua intenção de dissolver as separações entre prática e significado, atividade e objeto, corpo e cultura, produção e consumo de significados artísticos. Cada um tem dentro de si um artista 
484 Luisa Günther

possível. Ligia Dabul, com maestria, revelou o poder simbólico que comporta em sua própria alma.

\section{Notas}

1 Chipp, H. B. (Ed.). Teorias da arte moderna. São Paulo: Martins Fontes, 1999. 